Jurnal Indonesia Sosial Teknologi: p-ISSN: 2723 - 6609

e-ISSN : 2745-5254

Vol. 2, No. 11 November 2021

\title{
UNSUR PENYALAHGUNAAN WEWENANG OLEH PEJABAT PEMERINTAHAN DI INDONESIA
}

\section{Tanti Nur Ainun Azizah}

Jurusan Ilmu Hukum, Universitas Tarumanagara Jakarta

Email : tantitannn@gmail.com

\begin{abstract}
Abstrak
Pejabat Pemerintah adalah seseorang yang melaksanakan fungsi dari Pemerintahan, baik di lingkungan pemerintahan maupun penyelenggara negara. Untuk itu, pejabat pemerintah dilarang membuat suatu keputusan di luar ruang lingkup pekerjaan yang seharunya atau tindakan penetapan dalam pemerintahan yang berpotensi dapat menimbulkan sautu konflik kepentingan dalam Pemerintahan serta kerugiankerugian yang ditujukan ke negara. Seperti membuat kerugian yang berdampak kepada keuangan negara dan penyalahgunaan kewenangan lainnya yang dibuat secara sengaja. Berkaitan dengan hal tersebut, terdapat aturan larangan penyalahgunaan wewenang pejabat pemerintahan. Larangan penyalahgunaan wewenang tersebut meliputi larangan untuk melampaui batasan wewenang, larangan bertindak demi kepentingan pribadi maupun kerabat dekat, dan atau larangan bertindak sewenang-wenang di luar kapasitasnya. Hal ini Pejabat Pemerintah yang seharusnya melaksanakan fungsi dari Pemerintahan itu sendiri apabila menyalahgunakan kewenangan dalam jabatannya akan sangat menimbulkan kerugian bagi negara. Tujuan dilakukannya penelitian ini yaitu untuk mengetahui lebih jelas sejauh apa tugas dan wewenang dari Pejabat Pemerintah. Metode yang digunakan dalam penelitian ini menggunakan metode yuridis normatif (metode penelitian hukum normatif).
\end{abstract}

Kata kunci: penyalahgunaan wewenang; pejabat pemerintah; kerugian keuangan negara.

\section{Abstract}

Government official is someone who carries out the functions of the Government, both within the government and state administrators. For this reason, government officials may not make a decision outside the scope of work stipulated in the policy that may cause a conflict of interest within the Government and losses directed to the state. Such as making an impact that has an impact on state finances and other regulations that are made intentionally. In this regard, there is a prohibition that is authorized in the government. The authority prohibition includes a prohibition on the limits of authority, a prohibition on acting in the interests of personal or close relatives, and/or acting arbitrarily beyond their capacity. In this case, Government Officials who are supposed to carry out the functions of the Government itself if they abuse their authority in their positions will greatly cause harm to the state. The purpose of writing this paper is to find out more clearly what the duties and authorities of Government Officials are. The method used in this paper uses a normative juridical method (normative legal research method). 
Keywords: abuse of authority; government officials; loss of state finances.

\section{Pendahuluan}

Menurut Bagir Manan, dimensi sosial ekonomi dari negara berdasar hukum adalah berupa kewajiban negara atau pemerintah untuk mewujudkan kesejahteraan sosial (kesejahteraan umum) dalam suasana sebesar-besarnya kemakmuran menurut asas keadilan sosial bagi seluruh rakyat. Dimensi ini secara spesifik melahirkan paham negara kesejahteraan (verzorgingstaat, walfare state). Seanjutnya keadilan sosial bagi seluruh rakyat Indonesia yaitu bunyi dari Pancasila yakni sila ke-5, sesuai dengan bunyi tersebut diharapkan setiap warga negara Indonesia memiliki rasa tanggungjawab yang penuh dengan segenap hati dan jiwanya sebagaimana apabila menjadi seorang Pejabat Pemerintah harus memiliki rasa tanggungjawab untuk menjalankan tugas yang seharusnya dengan tidak semata-mata hanya untuk mementingkan kepentingan pribadinya saja melainkan untuk kesejahteraan rakyat dengan tidak menyalahgunakan kekuasaan yang dimilikinya. Karena sangat tidak mungkin jika seseorang hanya mementingkan dirinya sendiri tanpa adanya memerhatikan kepentingan masyarakat lainnya. Begitupun sebaliknya, hidup bermasyarakat juga tidak terlepas dan tidak mungkin melupakan kepentingan dirinya tanpa mementingan bangsa Indonesia dalam menjalankan tugas hidupnya yang bersifat sosial atau berlaku adil terhadap sesama. Mempunyai kekuasaan seharusnya Pejabat Pemerintah melakukan tugasnya dengan sebaik mungkin untuk bisa menyejahterakan rakyatnya. Sesuai dengan fungsinya, dalam hal ini Pejabat Pemerintah yang seharusnya melaksanakan fungsi dari Pemerintahan itu sendiri apabila menyalahgunakan kewenangan dalam jabatannya akan sangat menimbulkan kerugian bagi negara. Berkaitan dengan hal tersebut, terdapat aturan larangan penyalahgunaan wewenang pejabat pemerintahan. Misalnya, yang akan berdampak langsung dengan nasib rakyat yang akan menjadi terganggu kehidupannya terkait dengan perekonomian dan sosial. Hasil pajak-pajak yang telah mereka bayar apabila dana yang sudah terkumpul tersebut malah disalahgunakan oleh Pejabat Pemerintahnya itu sendiri. Hal ini menjadi sangat tidak sesuai dengan apa tugas dan fungsi Pejabat Pemerintah dengan mempunyai kekuasaan tersebut. Menjadi seorang Pejabat Pemerintah, alangkah baiknya bisa menyejahterakan rakyatnya untuk selalu menjalakan tugasnya dengan jujur dan tidak terpengaruhi oleh apapun dan siapapun dengan tidak pernah mengharapkan imbalan berupa apapun walaupun dirinya bisa melakukan hal tersebut karena jabatan atau posisi yang dimilikinya. Tujuan penelitian ini yakni untuk bisa menyadarkan generasi penerus bangsa yang ingin bercita-cita ingin menjadi seorang Pejabat Pemerintah agar tidak melakukan hal-hal atau tindakan di luar kapasitas kewenangannya maupun seorang yang telah memiliki kekuasaan tersebut.

\section{Metode Penelitian \\ Sifat dan Jenis Penelitian}


Metode penelitian yang digunakan dalam penelitian ini yaitu dengan menggunakan metode sesuai dengan judul dan permasalahan yang akan dibahas dalam tulisan ini yaitu agar dapat memberikan sebuah hasil yang bermanfaat dan mudah dipahami, maka penulisan ini dilihat dari jenis dan sifatnya dilakukan dengan penelitian menggunakan metode yuridis normatif (metode penelitian hukum normatif). Metode penelitian yuridis normatif adalah penelitian hukum kepustakaan yang dilakukan dengan cara meneliti bahan-bahan kepustakaan atau data sekunder yang sudah ada. Penelitian ini untuk mendapatkan bahan-bahan yakni berupa: asas-asas hukum, teori-teori hukum, konsep-konsep hukum, serta peraturan perundang-undangan yang ada dan telah diatur yang berhubungan dengan pokok permasalahan pada penelitian ini dengan menuangkan hasil, mendeskripsikan, dan menganalisa dari peraturan-peraturan hukum terkait bagaimana seharusnya dan bagaimana senyatanya.

\section{Hasil dan Pembahasan \\ Definisi Atau Ruang Lingkup}

Wewenang memiliki arti yaitu hak yang dimiliki oleh Badan dan/atau Pejabat Pemerintahan atau penyelenggara negara lainnya untuk mengambil keputusan dan/atau tindakan dalam penyelenggaraan pemerintahan (Ansori, 2017). Kemudian yang disebut dengan Penyalahgunaan wewenang adalah penggunaan wewenang oleh Badan dan/atau Pejabat Pemerintahan dalam mengambil keputusan dan/atau tindakan dalam penyelenggaraan pemerintahan yang dilakukan dengan melebihi wewenang dan kapastitas yang seharusnya diberikan atau dimiliki, dan/atau bertindak sewenang-wenang sebagaimana yang sudah diatur dalam Pasal 17 dan Pasal 18 Undang-Undang Nomor 30 Tahun 2014 tentang Administrasi Pemerintahan (Voll, 2010).

Terjadinya penyalahgunaan wewenang perlu diketahui dan diukur dengan membuktikan secara faktual dan akurat bahwa seorang pejabat telah menggunakan wewenangnya dilakukan untuk tujuan yang seharusnya atau tidak, hal ini harus dapat dibuktikan juga bahwa terjadinya penyalahgunaan wewenang dilakukan secara sadar atau sengaja dengan mengalihkan tujuan yang telah diberikan kepada wewenang itu (Harun, Nuria Siswi, SH, \& Galang Taufani, 2018). Pengalihan tujuan tersebut harus benar berdasarkan keinginan pribadi yang dilakukan dengan sadar atas sesuatu yang dilakukannya yakni diluar kapasitas kewenangannya, baik untuk kepentingan dirinya sendiri ataupun untuk orang-orang terdekat/kerabat.

(Hadjon, 2012) Berdasarkan tinjauan yuridis, penyalahgunaan wewenang dalam Undang-Undang Administrasi Pemerintahan dinyatakan terjadi ketika "badan dan/atau pejabat pemerintahan dalam membuat keputusan dan/atau melakukan tindakan yang dilakukan melebihi wewenang dengan:

a). melampaui masa jabatan berlakunya wewenang;

b). melampaui batas wilayah wewenang yang seharusnya; dan/atau

c). bertentangan dengan ketentuan peraturan perundang-undangan yang telah ada. 
Menurut ketentuan Pasal 17 Undang-Undang Nomor 30 Tahun 2014, badan dan/atau pejabat pemerintahan dilarang menyalahgunakan wewenang, larangan itu meliputi larangan melampaui wewenang, larangan mencampuradukkan wewenang, dan/atau larangan bertindak sewenang-wenang.

Badan dan/atau pejabat pemerintahan dikategorikan melampaui wewenang apabila keputusan dan/atau tindakan yang dilakukan melampaui masa jabatan atau batas waktu berlakunya wewenang, melampaui batas wilayah berlakunya wewenang; dan/atau bertentangan dengan ketentuan peraturan perundang-undangan ( Badan dan/atau pejabat pemerintahan dikategorikan mencampuradukkan wewenang apabila keputusan dan/atau tindakan yang dilakukan di luar cakupan bidang atau materi wewenang yang diberikan, dan/atau bertentangan dengan tujuan wewenang yang diberikan (Barhamudin, 2019). Badan dan/atau pejabat pemerintahan dikategorikan bertindak sewenang-wenang apabila keputusan dan/atau tindakan yang dilakukan tanpa dasar kewenangan, dan/atau bertentangan dengan putusan pengadilan yang berkekuatan hukum tetap.

Berdasarkan Pasal 20 UU Nomor 30 Tahun 2014, maka pengawasan dan penyelidikan terhadap dugaan penyalahgunaan wewenang terlebih dahulu dilakukan oleh Aparat Pengawasan Intern Pemerintah (APIP). Hasil pengawasan APIP terhadap dugaan penyalahgunaan wewenang berupa tidak terdapat kesalahan, terdapat kesalahan administratif, atau terdapat kesalahan administratif yang menimbulkan kerugian keuangan negara.

Asas-Asas Umum penyelenggaraan negara dalam Pasal 3 Undang-Undang Nomor 28 Tahun 1999 Tentang Penyelenggaraan Negara Yang Bersih dan Bebas dari Korupsi, Kolusi dan Nepotisme meliputi, a. Asas kepastian hukum; b. Asas tertib penyelenggaraan Negara; c. Asas kepentingan umum; d. Asas keterbukaan; e. Asas proposionalitas; f. Asas profesionalitas; dan g. Asas akuntabilitas.

Dasar pengujian ada atau tidaknya penyalahgunaan ini adalah dilihat berdasarkan dari peraturan dasar (legalitas) sebagai hukum positif tertulis yang melatar belakangi ada atau tidaknya kewenangan saat mengeluarkan suatu keputusan, artinya ukuran atau kriteria ada atau tidaknya unsur "menyalahgunakan kewenangan" haruslah menaati peraturan dasar mengenai tugas, kedudukan, fungsi, susunan organisasi dan ruang lingkup tata kerja.

Penyalahgunaan kewenangan ini diatur dalam Pasal 3 UU Nomor 31 Tahun 1999 jo Undang-Undang Nomor 20 Tahun 2001 bukanlah satu-satunya bentuk penyalahgunaan kewenangan. Selain penyalahgunaan kewenangan dalam Pasal 3 Undang-Undang Nomor 31 Tahun 1999 jo Undang-Undang Nomor 20 Tahun 2001.

(Simanjuntak, 2018) Lemahnya konsep penyalahgunaan wewenang dalam delik korupsi sebagaimana diatur dalam Pasal 3 Undang-Undang Pemberantasan Tindak Pidana Korupsi, semakin menegaskan bahwa korupsi merupakan "invisible crime" yaitu ketika aparat negara yang koruptif atau perbuatan koruptif berlindung di balik kebijakan (Rini, 2018). Dalam hal ini, Marwan Effendy memandang bahwa "telah terjadi pergeseran hukum yang akan menimbulkan kegamangan bagi pejabat tata usaha negara, 
manakala ia harus melaksanakan tugas, fungsi dan wewenangnya untuk menetapkan suatu kebijakan" (Dewi, 2019).

Di kalangan penegak aturan sendiri masih ada persepsi yang tidak sama pada menaruh batasan kapan kebijakan atau diskresi masuk pada ranah pidana atau sekedar pelanggaran administratif, khususnya pada kaitan menggunakan kebijakan atau tindakan yang keliru berdasarkan pejabat yang menyebabkan kerugian negara (Hadjon, 2011.).

\section{Kesimpulan}

Pengujian ada atau tidaknya penyalahgunaan kewenangan adalah dilihat berdasarkan dari peraturan dasar (legalitas) sebagai hukum positif tertulis yang melatar belakangi ada atau tidaknya kewenangan saat mengeluarkan suatu keputusan, artinya ukuran atau kriteria ada atau tidaknya unsur "menyalahgunakan kewenangan" haruslah menaati peraturan dasar mengenai tugas, kedudukan, fungsi, susunan organisasi dan ruang lingkup tata kerja. Kemudian, pejabat terkait dapat dikatakan menyalahgunakan wewenang apabila dalam persidangan di PTUN terbukti bahwa perbuatan mereka menerima dana bagi hasil pemungutan pajak bumi dan bangunan bertentangan dengan peraturan perundang-undangan, mengingat dasar hukum yang dijadikan alasan oleh mereka telah dicabut. Sebagai saran, bahwa dalam melaksanakan fungsi pemerintahan, maka pejabat pemerintahan dilarang menyalahgunakan wewenang. Seharusnya sebagai seorang pejabat yang mempunyai kekuasaan, memanfaatkan kekuasaannya tersebut untuk bisa menyejahterakan rakyatnya dan menciptakan perdamaian demi kepentingan umum bukan hanya untuk dirinya sendiri, kerabat, atau golongan-golongan tertentu. 
Unsur penyalahgunaan wewenang oleh Pejabat pemerintahan di Indonesia

\section{Bibliografi}

Ansori, Lutfil. (2017). Diskresi Dan Pertanggungjawaban Pemerintah Dalam Penyelenggaraan Pemerintahan. Jurnal Yuridis, 2(1), 135-150.

Barhamudin, Barhamudin. (2019). Penyalahgunaan Kewenangan Pejabat Pemerintahan Dan Ruang Lingkupnya Menurut Undang-Undang Administrasi Pemerintahan. Solusi, 17(2), 175-192.

Dewi, Arma. (2019). Penyalahgunaan Wewenang Dalam Perspektif Tindak Pidana Korupsi. Jurnal Rechten: Riset Hukum Dan Hak Asasi Manusia, 1, 24-40.

Hadjon, Philipus M. (n.d.). dkk.(2011). Hukum Administrasi Dan Tindak Pidana Korupsi.

Hadjon, Philipus M. (2012). dkk. Hukum Administrasi dan Good Governance. Jakarta.

Harun, S. H., Nuria Siswi, E., SH, M. H., \& Galang Taufani, S. H. (2018). Hukum Administrasi Negara: Di Era Citizen Friendly. Muhammadiyah university Press.

Hulu, Sabarudin, \& Pujiyono, Pujiyono. (2018). Pertanggungjawaban Pidana Atas Tindakan Diskresi Pejabat Pemerintahan Yang Berindikasi Adanya Penyalahgunaan Wewenang. Masalah-Masalah Hukum, 47(2), 167-174.

Rini, Nicken Sarwo. (2018). Penyalahgunaan Kewenangan Administrasi Dalam Undang Undang Tindak Pidana Korupsi. Jurnal Penelitian Hukum De Jure, 18(2), 257-274.

Simanjuntak, Enrico. (2018). Hukum acara peradilan tata usaha negara transformasi dan refleksi.

Voll, Willy D. S. (2010). Dasar-Dasar Ilmu Hukum Administrasi Negara.

Laica H.M. Marzuki,. "Pemberlakuan Undang-Undang Nomor 30 Tahun 2014 Tentang Administrasi Pemerintahan Dalam Konteks Perkembangan Kompetensi Peradilan Tata Usaha Negara RI", hlm. 13. Makalah disampaikan pada Seminar Sehari dalam rangka HUT Peradilan Tata Usaha Negara ke-26 dengan tema: Paradigma Baru Penyelenggaraan Pemerintahan Berdasarkan Undang-Undang Administrasi Pemerintahan, kaitannya dengan Perkembangan Hukum Acara Peratun, Hotel Mercure, Jakarta, 26 Januari 2016

Philiphus M Hadjon, "Peradilan Tata Usaha Negara Dalam Konteks Undang-Undang Nomor 30 Tahun 2014", disampaikan dalam Colloquium Membedah UndangUndang Nomor 30 Tahun 2014 Tentang Administrasi Pemerintahan, Hotel Garden Palace, 5 Juni 2015

Shinta Agustina dkk. Penjelasan Hukum Unsur Melawan Hukum; Penafsiran Unsur Melawan Hukum Dalam Pasal 2 Undang-Undang Pemberantasan Tindak Pidana Korupsi, Jakarta: Kerjasama Judicial Sector Support dengan LeIP, 2017

Romli Atmasasmita. "Penyalahgunaan Wewenang Oleh Penyelenggara Negara: Suatu Catatan Kristis Atas UU RI Nomor 30 Tahun 2014 tentang Administrasi 
Unsur penyalahgunaan wewenang oleh Pejabat pemerintahan di Indonesia

Pemerintahan Dihubungkan Dengan UU RI Nomor 20 Tahun 2001 tentang Perubahan Atas UU RI Nomor 31 Tahun 1999 tentang Pemberantasan Tindak Pidana Korupsi", Makalah, disampaikan dalam Seminar Nasional dalam rangka HUT IKAHI Ke-62 dengan tema "Undang-Undang Administrasi Pemerintahan, Menguatkan atau Melemahkan Upaya Pemberantasan Korupsi”, Hotel Mercure, Jakarta, tanggal 26 Maret 2015

Shinta Agustina dkk. Penjelasan Hukum Unsur Melawan Hukum; Penafsiran Unsur Melawan Hukum Dalam Pasal 2 Undang-Undang Pemberantasan Tindak Pidana Korupsi, Jakarta: Kerjasama Judicial Sector Support dengan LeIP, 2017 